\title{
Role of DNA mismatch repair genes in lung and head and neck cancer (Review)
}

\author{
SOTIRIOS G. DOUKAS ${ }^{1,2^{*}}$, DIMITRA P. VAGELI ${ }^{3 *}$, TAXIARCHIS KONSTANTINOS NIKOLOUZAKIS ${ }^{4}$, \\ LUCA FALZONE $^{5}$, ANCA OANA DOCEA ${ }^{6}$, GEORGE LAZOPOULOS ${ }^{7}$, \\ KONSTANTINOS KALBAKIS $^{8}$ and ARISTIDIS TSATSAKIS ${ }^{1}$ \\ ${ }^{1}$ Department of Forensic Sciences and Laboratory of Toxicology, Medical School, University of Crete, \\ 71003 Heraklion, Greece; ${ }^{2}$ Department of Internal Medicine, Saint Peter's University Hospital, \\ New Brunswick, NJ 08901; ${ }^{3}$ Department of Surgery, The Yale Larynx Laboratory, New Haven, CT 06510, USA; \\ ${ }^{4}$ Laboratory of Anatomy-Histology-Embryology, Medical School of Heraklion, University of Crete, \\ 71110 Heraklion, Greece; ${ }^{5}$ Department of Biomedical and Biotechnological Sciences, University of Catania, \\ 95123 Catania, Italy; ${ }^{6}$ Department of Toxicology, University of Medicine and Pharmacy of Craiova, \\ 200349 Craiova, Romania; Departments of ${ }^{7}$ Cardiothoracic Surgery and ${ }^{8}$ Medical Oncology, \\ Medical School, University of Crete, 71110 Heraklion, Greece
}

Received July 23, 2019; Accepted August 30, 2019

DOI: $10.3892 /$ wasj.2019.21

\begin{abstract}
The role of the DNA repair mechanism is to protect genetic material from destabilization. A defect in the DNA mismatch repair (MMR) mechanism has been associated with both hereditary and sporadic tumors. The dysregulation of MMR gene expression has been reported in lung, and in head and neck sporadic tumors. However, the mechanisms through which defects in the DNA MMR mechanism promote lung, and head and neck cancer remain unclear. Environmental factors and epigenetic alterations can significantly alter the ability of cells to repair genetic damage. The loss or a low expression of MMR genes allows for the survival of cells carrying a significant amount of genetic alterations, some in proto-oncogenes or genes regulating the cell cycle. The dysregulation or malfunction of the MMR mechanism has also been linked to alterations in response to chemotherapy. The investigation of MMR dysregulations in lung, and head and neck carcinomas may contribute to a better understanding of their biological role in the development and progression of
\end{abstract}

Correspondence to: Dr Sotirios G. Doukas, Department of Internal Medicine, Saint Peter's University Hospital, 254 Easton Avenue, New Brunswick, NJ 08901, USA

E-mail: sdoukas@saintpetersuh.com

*Contributed equally

Abbreviations: MMR, mismatch repair; MSI, microsatellite instability

Key words: MMR, lung cancer, head and neck cancer these types of cancer, and may thus also improve their diagnostic, prognostic and therapeutic value.

\section{Contents}

1. Mismatch repair genes and their role in carcinogenesis: The functions of the mismatch repair system

2. DNA mismatch repair deficiency in lung, and head and neck cancer

3. Conclusion

1. Mismatch repair genes and their role in carcinogenesis: The functions of the mismatch repair system

DNA repair gene products function together to protect the destabilization of genetic material by errors that occur during DNA replication. In this manner, they participate in preventing the multistep process of the neoplastic transformation of normal cells to the tumorigenic phenotype (1-7). Genetic damage to the DNA mismatch repair (MMR) mechanism may lead to microsatellite instability (MSI), a common finding in hereditary forms of cancer, such as hereditary nonpolyposis colorectal cancer (HNPCC) and hereditary endometrial cancer (8-16). Defects in the DNA repair mechanism have been observed in hereditary forms of cancer, and have been linked to specific syndromes. Previous studies have demonstrated that MSI and/or the loss of expression of MMR proteins or low levels of mRNA, are common findings in a number of sporadic cancers, such as lung, endometrial, ovarian and gastric cancers, where a loss of expression of MMR proteins or low levels of mRNA are common results of MMR gene promoter methylation (16-24). Similarly, there have been reported cases of the increased expression of 
MMR genes in sporadic colon, prostate or urinary bladder cancers, supporting the theory of their complex role in carcinogenesis (25-30).

DNA MMR mechanism. The main role of the MMR mechanism is to recognize and repair single-base mismatch errors, such as insertion, deletion and mis-incorporation that can occur during DNA replication. The recognition of the error and subsequent activation of the mechanism depends on the enzymatic complex of the proteins, MutS, MuH and MutL (31). The MutS complex has the ability to recognize mismatched nucleotides and bind to the damaged DNA. The MuH complex attaches to the hemimethylated sites along the impaired fragment, while the MutL complex activates the MutH peptide, which acts as a mediator between MutS and MutH (4-6).

One of the most crucial part of this system is the mutS-Homolog 2 (MSH2) gene. $M S H 2$ codes a protein which participates in the formation of two functional heterodimers: MSH2-MSH6 (MutS $\alpha$ ) and MSH2-MSH3 (MutS $\beta$ ) that recognize DNA mismatches (base-base mismatches and short insertion-deletion loops) and large DNA loops (insertion-deletion) respectively (Fig. 1).

Mismatch errors promote ATP hydrolysis, resulting in a change in the configuration of the MSH2-MSH6 complex to slide from its DNA binding site and to perform the repair. The complex acts as ATPase by hydrolyzing ATP. The release of the complex from the DNA does not depend on its activity as ATPase (1,30).

In addition to the DNA damage recognition complexes, the mismatch DNA repair mechanism in humans includes MutL complexes that relate to MLH1-MLH3 and MLH1-PMS2 heterodimers (possibly also the MLH1-PMS1 complex) $(32,33)$. MLH1-MLH3 binds to MutSa (MSH2-MSH6) by converting it to a large complex. The MutL complexes interact with the damage recognition complexes and with other proteins that function in the action of the MMR mechanism, such as exonucleases (for example EXO1), DNA polymerases ( $\delta$ and $\varepsilon$ ), replicating agents, helicases and PCNA to repair the damage (32).

DNA MMR deficiency and carcinogenesis. Defects in DNA recognition complexes of the MMR system (MutS $\alpha$ and MutS $\beta$ ) have been observed in humans. Specifically, a deficiency in the expression of DNA MMR genes is almost always followed by the alteration of the number of short tandem repeats, known as MSI, and this leads to the development of a number of known types of carcinomas (34-36) (Fig. 2).

Defective DNA MMR mechanism leads to carcinogenesis. In hereditary forms of cancer, the defective repair mechanism can be caused by inherited mutations in coding regions of a replication gene allele and loss of heterozygosity $(\mathrm{LOH})$ or acquired mutations in the other allele, and is depicted as a loss of MMR expression or increased MSI (30). The most common recognized and studied syndrome is Lynch syndrome characterized by the alteration of $h M S H 2$ and $h M L H 1$ genes altered, respectively, in 60 and $30 \%$ of patients with Lynch syndrome (37). These mutations are responsible for MSI. Notably, both Lynch syndrome and MSI are predisposing conditions for the development of several tumors. In particular, patients with type I Lynch syndrome are more susceptible to the development of colorectal cancer, while patients with

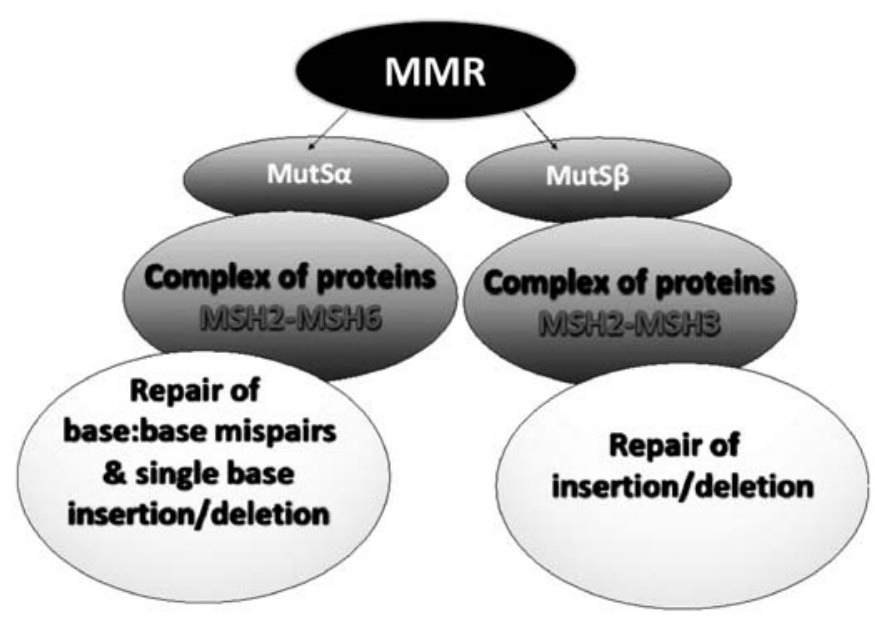

Figure 1. MMR complexes. The most crucial protein complexes of the DNA MMR mechanism that recognize the DNA mismatches are MutS $\alpha$ and MutS $\beta$. The MutS $\alpha$ recognizes base substitution, mutations and short DNA loops, while MutS $\beta$ recognizes large DNA loops. MMR, mismatch repair.

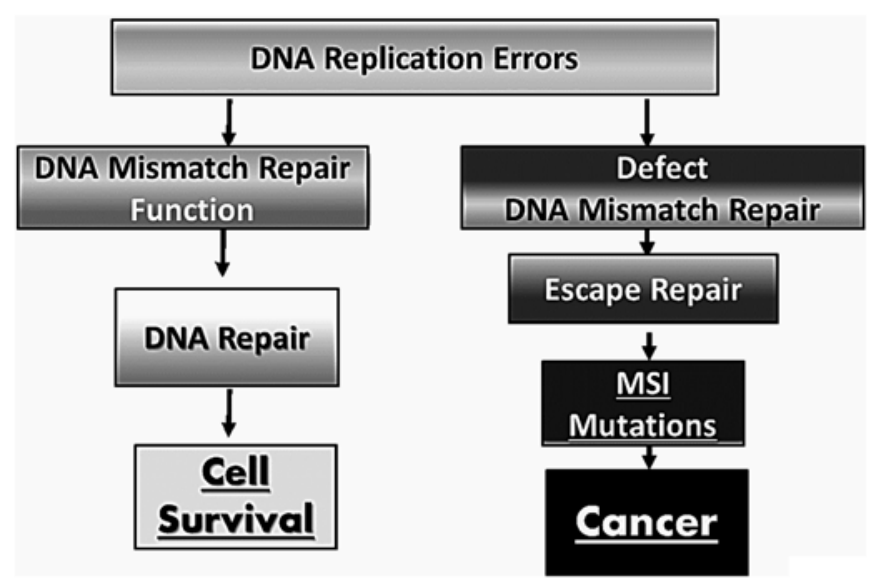

Figure 2. Dysregulated DNA MMR mechanism and carcinogenesis. Replication errors can be repaired by a functional DNA MMR mechanism that is capable of recognizing and successfully repairing these errors. The dysregulated DNA MMR mechanism cannot recognize the DNA replication errors leading to genetic alterations, such as MSI and/or mutations in functional sites of DNA that subsequently may lead to carcinogenesis. MMR, mismatch repair; MSI, microsatellite instability.

type II Lynch syndrome have an increased risk of developing gastric cancer, urological malignancies, cholangiocarcinoma and colon cancer (38-42)

Besides this syndrome, other genetic and epigenetic alterations in the $h M S H 2, h M L H 1, h M S H 6, h M S H 3, h P M S 2$ and hPMS1 genes can cause damage to the DNA repair mechanism resulting in increased levels of genetic instability recognized as elevated MSI rates (32).

Recent studies have demonstrated that numerous sporadic tumors exhibit MSI without harboring any mutations in the repair genes (43), probably due to epigenetic alterations in the transcription and translation of MMR genes $(30,44)$. Specifically, in sporadic cancers, the loss or low levels of MMR protein expression or mRNA depicted as increased MSI, due to the hypermethylation of hMLH1, or in some cases the hMSH2 promoter, causes the suppression of their expression and compromises the function of the MMR mechanism (22,30). 


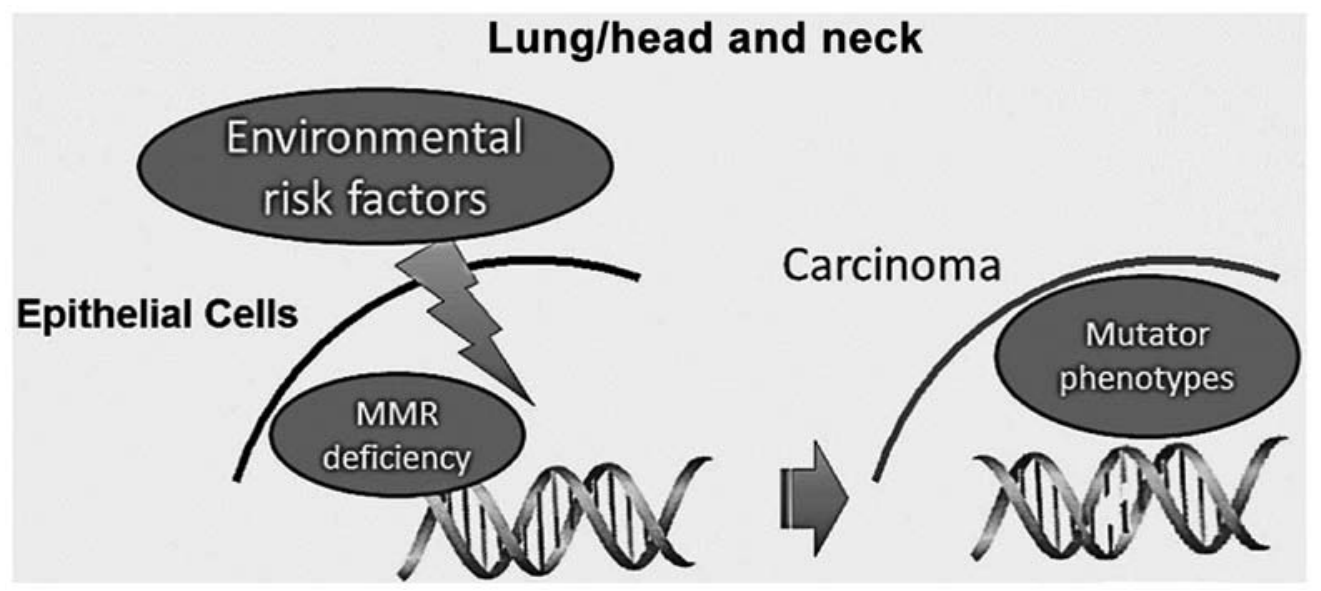

Figure 3. Environmental risk factors and DNA MMR deficiency may lead to neoplastic transformation in lung and head and neck. Lung and head and neck normal epithelial cells are often exposed to different environmental risk factors. Repetitive exposure of these cells to various risk factors may result to the accumulation of replication errors due to a defective DNA MMR mechanism. DNA mismatch repair deficiency may lead to a mutator phenotype escaping cell control and resulting to a neoplastic transformation of normal cells giving genesis to cancer. MMR, mismatch repair.

In general, the loss or low expression of MMR is evidence of a faulty repair mechanism constituting either a genetic background of cancer transformation in hereditary cancers, allowing for an increased MSI in cells, or promoting the tumorigenic pathway in sporadic cancers, allowing for the survival of cells carrying a significant amount of genetic alterations, some in proto-oncogenes or genes regulating the cell cycle.

The $h M S H 2$ and $h M L H 1$ genes are the most frequently involved in such changes. In fact, the MSH2 protein is normally expressed 3-5-fold above the protein levels of MLH1 expression, which in turn can be expressed 1.5-2.5-fold over PMS2 (45). In general the expression levels of MSH2 determine the expression levels of MSH3 and MSH6. Loss or low levels of MSH2 result in unstable MSH3 and MSH6 structures that are reflected by low levels of their proteins in the cells. Mutations in hMLH1 can also result in low levels of MLH1 and PMS2 proteins, showing their interrelated relationship (PMS2 interacts with MLH1).

Defects that lead to the suppression of MSH6 expression, may result in an increase in MSH3 mRNA and protein expression. It is clear that balanced expression levels of components of the MMR system are essential for effective repair functions $(2,32,45)$. Vageli et al previously demonstrated an association between an imbalanced mRNA phenotype of MMR genes and cancer progression in human lung, colorectal and urinary bladder cancer (18,46-49).

The importance of MMR function as an indicator of chemotherapeutic resistance. MSH2 protein, which is a major factor of base pair recognition error in DNA, under physiological conditions, is equated between the nucleus and cytoplasm. MSH2 has a high affinity for binding to the damaged site, which can be repaired, while having low affinity binding for non-severe damage that does not allow for cell viability, leading to apoptosis. The process of the initiation of apoptosis by MMR protein components appears to be related to their concentration in the nucleus. The concentration of MSH2 in the nucleus is a criterion for triggering apoptosis. Therefore, the loss or decreased expression levels of MSH2, will lead to an insufficient nuclear concentration of MMR and therefore, in the inability of cells carrying extensive DNA damage to undergo apoptosis $(31,50)$.

A number of studies have demonstrated that there is an association between the transcriptional activity of MMR mechanisms and the development of resistance to chemotherapy. Specifically, there is evidence that the inactivation of hMLH1 by promoter hypermethylation promotes chemotherapeutic resistance $(36,51,52)$. On the other hand, an imbalance in MMR mRNA phenotypes has been suggested to be of possible prognostic value in adjuvant chemotherapy treatment in non-small cell lung carcinomas (NSCLCs). Specifically, specific increased MMR mRNA phenotypes exhibit a trend for improved survival following chemotherapy, compared to other decreased mRNA phenotypes, which appear to be more effective in combination with post-operative chemotherapy (46).

Epigenetic regulation of MMR mechanism. The efficacy of the MMR mechanism can be strongly influenced by various environmental factors and epigenetic alterations that can significantly affect the ability of cells to repair genetic damage. These risk factors are able to determine profound epigenetic alterations, including the modulation of DNA methylation levels and microRNA (miRNA or miR) expression levels (53). The epigenetic regulation of MMR may be also associated with the composition of gut microbiota. This may strongly influence the development of several pathologies, including cancer $(54,55)$.

MMR and methylation. Westwood et al demonstrated that the promoter hyper-methylation of $M L H 1$ was responsible for the additional loss of $M S H 2$ and $M S H 6$ expression in sporadic colorectal cancer (56). Other researchers have demonstrated that the methylation of MMR genes is responsible for the development of other tumors, such as extra mammary Paget's disease, where the authors demonstrated a significant correlation between reduced $\mathrm{MSH} 2$ expression and its promoter hyper-methylation (57). In general, several studies have demonstrated a strong association between methylation phenomena and Lynch syndrome, highlighting how patients with this syndrome have an increased risk of 
DNA mutation accumulation due to genetic alterations typical of Lynch syndrome and the modulation of MMR induced by hyper-methylation (58).

miRNA and MMR regulation. As regards miRNAs, they are short (approximately 22 nucleotides in length) single-stranded non-translational RNAs that contribute to the regulation of gene expression (59). Specifically, they have the ability to target specific mRNAs, destabilizing or inhibiting their translation. The precursors of miRNAs, also known as pri-miRNAs, are produced in the nucleus by RNA polymerase II from the non-coding regions of the genome, and undergo a process of maturation in the nucleus, by the Drosha-DGCR8 complex, leading to hairpin RNAs known as precursor miRNAs (pre-miRNAs). The pre-miRNAs are then transported from the nucleus to the cytoplasm by exportin-5 and cut by Dicer to form single-strand miRNAs, the final functional form of miRNA. The majority of miRNAs inhibit the translation of their target genes by binding with an imperfect matching to their 3'UTR. In some cases, miRNAs can inhibit the protein expression of their target genes by binding the 3'UTR with a perfect match, leading to mRNA cleavage (60). The function of miRNAs in either case is to inhibit the protein expression of their genes. Therefore, these small regulatory molecules have been proposed as useful targets for the treatment of several pathological conditions, as well as markers for early neoplastic changes (61-66).

In particular, miRNAs have been shown to be involved in the regulation of numerous genes associated with various physiological processes, including MMR genes (67-72). Mao et al demonstrated that MutLa could function as a stimulatory factor for miRNA processing (73), while Valeri et al demonstrated the capability of miR-155 to alter both the expression and stability of the MMR pathway, supporting a regulatory role of miR-155 in the MMR mechanism (74). Zhong et al suggested that miRNAs play an important role in modulating the cell cycle by targeting $h M S H 2$ in lung cancer (75).

Overall, the unbalance of the MMR mechanism and the acquisition of new oncogenic mutations are the result of different genetic and epigenetic alterations. These alterations in expression can be identified using innovative and high-sensitive techniques (76), providing information with which to predict the risk of cancer onset and to identify novel biomarkers and therapeutic targets.

\section{DNA mismatch repair deficiency in lung, and head and neck cancer}

Lung and head and neck carcinogenesis is strongly associated with known risk factors, such as alcohol, tobacco smoking and oncoviruses, causing DNA damage. It is considered that the extensive accumulation of genetic alterations in DNA by these environmental risk factors may lead to an abnormal DNA damage response (DDR), which can result in cell death, chromosomal instability and unregulated proliferation (77-80). Therefore, the proper function of the various DNA repair mechanisms is essential for the elimination of these harmful effects, maintaining the DNA integrity (Fig. 3).

Head and neck cancer and MMR. Thus far, a number of studies have suggested that polymorphisms of MMR are associated with an increased risk of developing head and neck cancer (81-83). A number of studies have shown that head and neck squamous cell carcinomas (HNSCCs) very often exhibit MSI. Notably, it has been observed that HNSCCs exhibit MSI at higher rates than other solid tumors, such as esophageal, breast and gastric carcinomas (21-24,40,84,85). Demokan et al, also showed that high levels of MSI in HNSCC are strongly associated with hypermethylation of $h M L H 1$ and $h M S H 2$ (81).

As has been discussed above, the dysfunction of the MMR mechanism can lead to MSI and to the accumulation of mutations in proto-oncogenes or tumor-suppressor genes, increasing the risk of malignant development and progression. It has already been demonstrated that the decreased expression of the MSH2 gene causally increases the frequency of MSI $(86,87)$. Furthermore, the investigation of the MSH2 protein level in surgical specimens of head and neck carcinoma have revealed an association between low MSH2 levels and locoregional metastasis, as well as a worse survival (88).

In addition, a specific polymorphism of the MMR genes, $M L H 1, M S H 2$ and $M S H 3$, as well as EXO1, has been suggested to have prognostic value for HNSCC, particularly among smokers (89). Moreover, a recent study also provided evidence that a single nucleotide polymorphism in the hMLH1 promoter was associated with tobacco-related oral squamous cell carcinoma (90).

The hypermethylation of the $h M L H 1$ promoter, leading to the inactivation of the gene, has been shown to be an important epigenetic mechanism and has been linked to numerous human malignancies. The promoter hypermethylation of the hMLH1 gene has been also demonstrated in HNSCC (91-93). Specifically, Tawfik et al demonstrated that the loss of MLH1 protein was not an uncommon finding in HNSCC, and the common mechanism involved the methylation of the $\mathrm{CpG}$ inland of its promoter (94).

\section{Lung cancer and $M M R$}

Role of MMR in NSCLC. Previous studies have demonstrated a reduced expression of MSH2 or MLH1 genes at the protein or mRNA level in $>50 \%$ of lung adenocarcinomas, associated with a poor survival and an increase in MSI (95-96). Kanellis et al evaluated the protein expression levels of MMR genes in fine-needle aspiration (FNA) specimens derived from various types of lung cancer. Their study demonstrated that that NSCLCs, and particularly squamous cell carcinomas, exhibited reduced MSH2 protein levels at relatively high rates compared to small cell carcinomas (97).

Although in the majority of cases, the decreased expression of MMR genes is attributed to epigenetic silencing, other studies have indicated that MMR deficiency may act as a 'second hit', accelerating the development of lung tumors in mice that carry the K-ras ${ }^{\mathrm{LA} 1 /+}$ mutation (98). Specifically, Downey and Jirik, using a murine animal model, recently demonstrated that a deficiency in MMR genes can act in concert with the extremely common K-ras mutation, enhancing tumor development (98).

Wang et al suggested that $h M L H 1$ was the major altered MMR gene involved in NSCLC tumorigenesis, and that the methylation of its promoter was the most common mechanism for its dysregulation (19). Others have also suggested that the hypermethylation of $h M S H 2$ has prognostic value, particularly for non-smoking females (96). Although a reduction in the expression of MMR genes has been linked to a poor prognosis, 
Scartozzi et al demonstrated that a decreased MLH1 protein expression was associated with a statistically significant improvement in survival compared to normal MLH1 protein levels (99). A well-accepted explanation for similar findings does not exist thus far; however, it is possible that the loss of MLH1 leads to the accumulation of a tremendous number of replications errors, leading to a decrease in the division rates of cells. Finally, Takahashi et al demonstrated that the expression of the MLH1 and MSH2 proteins was significantly reduced in cromate-related (chromate-exposed) lung cancer, demonstrating high replication error rates (100).

$M M R$ deficiency affects the chemotherapy treatment of NSCLC. Taking into consideration that platinum-based chemotherapy is commonly used for advanced NSCLC (101), the determination of molecular markers indicating chemotherapeutic resistance has tremendous clinical value, potentially leading to the evidence-based selection of chemotherapy and the improvement of survival rates. A significant number of pre-clinical and clinical data have suggested that the inactivation of $h M L H 1$ and $h M S H 2$ promotes resistance to cisplatin and carboplatin-based chemotherapy, but not oxaliplatin-based chemotherapy $(99,102,103)$. According to Vageli et al, reduced mRNA levels of MMR are not beneficial for cisplatin chemotherapy, resulting in low survival rates in patients with NSCLC (46). Although the underlying mechanism of this phenomenon is not yet clear, it is considered that an efficient MMR system recognizes the DNA adducts produced by cisplatin and by its attempt to process the extensive number of adducts, activates a sequence of signals that lead to apoptosis (102). As a result, the dysfunction of the MMR system compromises the ability of the cell to detect chemotherapy-induced DNA damage and as a consequence, the ability to undergo apoptosis. On the other hand, pre-clinical analyses have suggested the ability of cells to recognize and react to the DNA damage induced by the drug oxaliplatin does not rely on the MMR system (103). Scartozi et al provided evidence based on clinical data that a decrease in the expression levels of MMR genes does not influence the sensitivity to oxaliplatin (99), confirming previously published pre-clinical data (103).

More recently, some studies have focused on the prognostic significance of a defective MMR mechanism and MSI in several types of cancer, including NSCLC $(104,105)$, and the responsiveness of patients towards immune check-point inhibitors (106-108). Overall, it is well-recognized that patients with MSI and/or defective MMR have generally a durable complete response (106). Furthermore, MSI has been shown to be a good predictive biomarker for immunotherapy efficacy in several types of cancer treated with pembrolizumab or nivolumab, including NSCLC, advanced melanoma, renal cell carcinoma, bladder cancer, etc $(107,108)$. As regards NSCLC, studies have demonstrated a high response rate following treatment with the immune check-point inhibitor, pembrolizumab, in the KEYNOTE-001 and KEYNOTE-024 trials $(109,110)$. Further clinical trials consisting of a sufficient number of NSCLCs patients and adequate follow-up are necessary to verify the efficacy of pembrolizumab in patients with microsatellite instability high/deficiency MMR (MSI-H/dMMR).

Role of MMR in small-cell lung carcinomas (SCLCs). The role of the MMR mechanism in SCLC is not yet clear. Data exploring the expression levels of MMR genes and MSI in
SCLC specimens have yielded controversial results. Although Pylkkänen et al reported rates of MSI close to zero (111), a number of other studies have shown that the prevalence of MSI in SCLC can reach up to 76\% (112-114). These differences have been attributed to the different microsatellite loci analyzed $(112,115)$. Kanellis et al reported that small cell carcinomas did not exhibit a significant reduction in MSH2 levels (97). In addition, Hansen et al examined the activity of MMR genes at the mRNA and protein level and their association with MSI in 17 SCLC cell lines, supporting that there was a heterogeneous expression pattern of MMR genes and that MMR consequent MSI was not that common in SCLC (115).

\section{Conclusion}

DNA repair deficiency is a hallmark in cancer development and may affect the therapeutic outcomes. Sporadic head and neck and lung tumors often exhibit genetic alterations due to an inadequate mismatch DNA repair mechanism. The mechanisms through which defects in the DNA MMR mechanism promote lung, and head and neck cancer are not yet clear. To the best of our knowledge, the present review article is the first attempt to summarize what is known in the literature about the dysregulation of this mechanism and its role in these types of cancer. This review supports the further investigation of alterations in the expression of mismatch DNA repair genes, at both the transcriptional and translational level, in head and neck, and lung sporadic tumors, clarifying their prognostic and diagnostic value, as well as their therapeutic potential as novel targets.

\section{Acknowledgements}

Not applicable.

\section{Funding}

No funding was received.

\section{Availability of data and materials}

Not applicable.

\section{Authors' contributions}

SGD and DPV were involved in the conceptualization and in the design of this review article. TKN and GL, were involved in searching the literature for the paragraphs 'DNA mismatch repair mechanism' and 'head and neck cancer and MMR'. LF was involved in searching the literature for paragraphs 'Epigenetic regulation of MMR mechanism' and 'MMR deficiency affects the chemotherapy treatment of NSCLC'. KK was involved in searching the literature for the paragraph 'the importance of MMR function as an indicator of chemotherapeutic resistance'. AOD and AT were involved in searching the relevant literature and databases for the paragraph 'DNA MMR deficiency and carcinogenesis'. SGD and DPV were involved in the preparation of the original draft and in the preparation of the figures. SGD and DPV were involved in the 
writing of the original draft. DPV, SGD, TKN, LF, AT and GL reviewed and edited the article. All authors have read and approved the final manuscript.

\section{Ethics approval and consent to participate}

Not applicable.

\section{Patient consent for publication}

Not applicable.

\section{Competing interests}

The authors declare that they have no competing interests.

\section{References}

1. Peltomäki P: DNA mismatch repair and cancer. Mutat Res 488 : 77-85, 2001.

2. Peltomäki P: Role of DNA mismatch repair defects in the pathogenesis of human cancer. J Clin Oncol 21: 1174-1179, 2003.

3. Li GM: DNA mismatch repair and cancer. Front Biosci 8: d997-d1017, 2003.

4. Yang W: Structure and mechanism for DNA lesion recognition. Cell Res 18: 184-197, 2008.

5. Kolodner RD: Mismatch repair: Mechanisms and relationship to cancer susceptibility. Trends Biochem Sci 20: 397-401, 1995.

6. Jiricny $\mathrm{J}$ and Nyström-Lahti M: Mismatch repair defects in cancer. Curr Opin Genet Dev 10: 157-161, 2000.

7. Aarnio M, Sankila R, Pukkala E, Salovaara R, Aaltonen LA, de la Chapelle A, Peltomäki P, Mecklin JP and Järvinen $\mathrm{HJ}$ : Cancer risk in mutation carriers of DNA-mismatch-repair genes. Int J Cancer 81: 214-218, 1999.

8. Bohr VA: DNA repair fine structure and its relations to genomic instability. Carcinogenesis 16: 2885-2892, 1995.

9. Kruhøffer M, Jensen JL, Laiho P, Dyrskjøt L, Salovaara R, Arango D, Birkenkamp-Demtroder K, Sørensen FB, Christensen LL, Buhl L, et al: Gene expression signatures for colorectal cancer microsatellite status and HNPCC. Br J Cancer 92: 2240-2248, 2005.

10. Leach FS, Nicolaides NC, Papadopoulos N, Liu B, Jen J,Parsons R, Peltomäki P, Sistonen P, Aaltonen LA, Nyström-Lahti M, et al: Mutations of a mutS homolog in hereditary nonpolyposis colorectal cancer. Cell 75: 1215-1225, 1993.

11. Fishel R, Lescoe MK, Rao MRS, Copeland NG, Jenkins NA, Garber J, Kane M and Kolodner R: The human mutator gene homolog MSH2 and its association with hereditary nonpolyposis colon cancer. Cell 75: 1027-1038, 1993.

12. Liu B, Nicolaides NC, Markowitz S, Willson JKV, Parsons RE, Jen J, Papadopolous N, Peltomäki P, de la Chapelle A, Hamilton SR, et al: Mismatch repair gene defects in sporadic colorectal cancers with microsatellite instability. Nat Genet 9: $48-55,1995$.

13. Liu B, Parsons R, Papadopoulos N, Nicolaides NC, Lynch HT, Watson P, Jass J, Dunlop M, Wyllie A, Jessup JM Peltomäki PT, et al: Mismatch repair gene analysis in HNPCC patients. Nat Med 2: 169-174, 1996.

14. Kowalski LD, Mutch DG, Herzog TJ, Rader JS and Goodfellow PJ: Mutational analysis of MLH1 and MSH2 in 25 prospectively-acquired RER+ endometrial cancers. Genes Chromosomes Cancer 18: 219-227, 1997.

15. Chadwick RB, Pyatt RE, Niemann TH, Richards SK, Johnson CK, Stevens MW, Meek JE, Hampel H, Prior TW and de la Chapelle A: Hereditary and somatic DNA mismatch repair gene mutations in sporadic endometrial carcinoma. J Med Genet 38: 461-466, 2001.

16. Soliman PT and Lu K: Endometrial cancer associated with defective DNA mismatch repair. Obstet Gynecol Clin North Am 34: 701-715, viii, 2007.

17. Rosen DG, Cai KQ, Luthra R and Liu J: Immunohistochemical staining of hMLH1 and hMSH2 reflects microsatellite instability status in ovarian carcinoma. Mod Pathol 19: 1414-1420, 2006 .
18. Vageli D, DaniilZ, Dahabreh J,Karagianni E, Vamvakopoulou DN, Ioannou MG, Scarpinato K, Vamvakopoulos NC, Gourgoulianis KI and Koukoulis GK: Phenotypic mismatch repair hMSH2 and hMLH1 gene expression profiles in primary non-small cell lung carcinomas. Lung Cancer 64: 282-288, 2009.

19. Wang YC, Lu YP, Tseng RC, Lin RK, Chang JW, Chen JT, Shih CM and Chen CY: Inactivation of hMLH1 and hMSH2 by promoter methylation in primary non-small cell lung tumors and matched sputum samples. J Clin Invest 111: 887-895, 2003.

20. Xinarianos G, Liloglou T, Prime W, Sourvinos G, Karachristos A, Gosney JR, Spandidos DA and Field JK: p53 status correlates with the differential expression of the DNA mismatch repair protein MSH2 in non-small cell lung carcinoma. Int J Cancer 101: 248-252, 2002

21. Kitajima Y, Miyazaki K, Matsukura S, Tanaka M and Sekiguchi M: Loss of expression of DNA repair enzymes MGMT, $\mathrm{hMLH} 1$, and hMSH2 during tumor progression in gastric cancer. Gastric Cancer 6: 86-95, 2003.

22. Tahara E: Genetic pathways of two types of gastric cancer. IARC Sci Publ 157: 327-349, 2004.

23. Nardone G, Rocco A and Budillon G: Molecular alteration of gastric carcinoma. Minerva Gastroenterol Dietol 48: 189-193, 2002.

24. El-Rifai W and Powell SM; EI-Rifai W: Molecular biology of gastric cancer. Semin Radiat Oncol 12: 128-140, 2002

25. Sasaki S and Nakamura Y: Mutation of the mismatch repair genes for carcinogenesis of sporadic colorectal cancers with RER-positive phenotype. Nihon Rinsho 54: 1008-1013, 1996. (In Japanese)

26. Wallis $\mathrm{Y}$ and Macdonald $\mathrm{F}$ : The genetics of inherited colon cancer. Clin Mol Pathol 49: M65-M73, 1996.

27. Burger M, Denzinger S, Hammerschmied CG, Tannapfel A, Obermann EC, Wieland WF, Hartmann A and Stoehr R: Elevated microsatellite alterations at selected tetranucleotides (EMAST) and mismatch repair gene expression in prostate cancer. J Mol Med (Berl) 84: 833-841, 2006.

28. Kassem HS, Varley JM, Hamam SM and Margison GP: Immunohistochemical analysis of expression and allelotype of mismatch repair genes (hMLH1 and hMSH2) in bladder cancer. Br J Cancer 84: 321-328, 2001

29. Leach FS, Hsieh JT, Molberg K, Saboorian MH, McConnell JD and Sagalowsky AI: Expression of the human mismatch repair gene hMSH2: A potential marker for urothelial malignancy. Cancer 88: 2333-2341, 2000.

30. Kuismanen SA, Holmberg MT, Salovaara R, de la Chapelle A and Peltomäki P: Genetic and epigenetic modification of MLH1 accounts for a major share of microsatellite-unstable colorectal cancers. Am J Pathol 156: 1773-1779, 2000.

31. Viale G, Trapani D and Curigliano G: Mismatch repair deficiency as a predictive biomarker for immunotherapy efficacy. BioMed Res Int 2017: 4719194, 2017.

32. Hsieh P and Yamane K: DNA mismatch repair: Molecular mechanism, cancer, and ageing. Mech Ageing Dev 129: 391-407, 2008.

33. Kijas AW, Studamire B and Alani E: Msh2 separation of function mutations confer defects in the initiation steps of mismatch repair. J Mol Biol 331: 123-138, 2003.

34. Gurin CC, Federici MG, Kang L and Boyd J: Causes and consequences of microsatellite instability in endometrial carcinoma. Cancer Res 59: 462-466, 1999.

35. Hayashi M, Tamura G, Jin Z, Kato I, Sato M, Shibuya Y, Yang S and Motoyama T: Microsatellite instability in esophageal squamous cell carcinoma is not associated with $h M L H 1$ promoter hypermethylation. Pathol Int 53: 270-276, 2003.

36. Nikolouzakis TK, Vassilopoulou L, Fragkiadaki P, Mariolis Sapsakos T, Papadakis GZ, Spandidos DA, Tsatsakis $\mathrm{AM}$ and Tsiaoussis J: Improving diagnosis, prognosis and prediction by using biomarkers in CRC patients (Review). Oncol Rep 39: 2455-2472, 2018. (Review).

37. Lynch HT, Snyder CL, Shaw TG, Heinen CD and Hitchins MP: Milestones of Lynch syndrome 1895-2015. Nat Rev Canc 15: 181-194, 2015.

38. Antelo M, Golubicki M, Roca E, Mendez G, Carballido M, Iseas S, Cuatrecasas M, Moreira L, Sanchez A, Carballal S, et al: Lynch-like syndrome is as frequent as Lynch syndrome in early-onset nonfamilial nonpolyposis colorectal cancer. Int J Cancer 145: 705-713, 2019.

39. Carethers JM and Stoffel EM: Lynch syndrome and Lynch syndrome mimics: The growing complex landscape of hereditary colon cancer. World J Gastroenterol 21: 9253-9261, 2015. 
40. Adar T, Friedman M, Rodgers LH, Shannon KM, Zukerberg LR, Chung DC: Gastric cancer in Lynch syndrome is associated with underlying immune gastritis. J Med Genet: doi: 10.1136/jmedgenet-2018-105757 (Epub ahead of print)

41. Wang J, Greenberg S and Yates J: Lynch syndrome-associated upper tract urothelial carcinoma. Urology 121: 19-21, 2018.

42. Cloyd JM, Chun YS, Ikoma N, Vauthey JN, Aloia TA, Cuddy A, Rodriguez-Bigas MA and Nancy You Y: Clinical and genetic implications of DNA mismatch repair deficiency in biliary tract cancers associated with lynch syndrome. J Gastrointest Cancer 49: 93-96, 2018.

43. Anacleto C, Leopoldino AM, Rossi B, Soares FA, Lopes A, Rocha JC, Caballero O, Camargo AA, Simpson AJ and Pena SD: Colorectal cancer 'methylator phenotype': Fact or artifact? Neoplasia 7: 331-335, 2005.

44. Imai $\mathrm{K}$ and Yamamoto $\mathrm{H}$ : Carcinogenesis and microsatellite instability: The interrelationship between genetics and epigenetics. Carcinogenesis 29: 673-680, 2008.

45. Chang DK, Ricciardiello L, Goel A, Chang CL and Boland CR Steady-state regulation of the human DNA mismatch repair system. J Biol Chem 275: 18424-18431, 2000.

46. Vageli DP, Zaravinos A, Daniil Z, Dahabreh J, Doukas SG, Spandidos DA, Gourgoulianis KI and Koukoulis GK: hMSH2 and hMLH1 gene expression patterns differ between lung adenocarcinoma and squamous cell carcinoma: Correlation with patient survival and response to adjuvant chemotherapy treatment. Int J Biol Markers 27: e400-e404, 2013.

47. Vageli DP, Giannopoulos S, Doukas SG, Kalaitzis C Giannakopoulos S, Giatromanolaki A, Koukoulis GK and Touloupidis S: Mismatch repair hMSH2, hMLH1, hMSH6 and hPMS2 mRNA expression profiles in precancerous and cancerous urothelium. Oncol Lett 5: 283-294, 2013.

48. Vageli DP, Doukas SG and Markou A: Mismatch DNA repair mRNA expression profiles in oral melanin pigmentation lesion and hamartomatous polyp of a child with Peutz-Jeghers syndrome. Pediatr Blood Cancer 60: E116-E117, 2013.

49. Vageli DP, Papamichali R, Kambosioras K, Papandreou CN and Koukoulis GK: Mismatch DNA repair $h M S H 2, h M L H 1, h M S H 6$ and $h P M S 2$ mRNA expression profiles in colorectal carcinomas J Genet Syndr Gene Ther: doi: 10.4172/2157-7412.1000191.

50. Christmann M and Kaina B: Nuclear translocation of mismatch repair proteins MSH2 and MSH6 as a response of cells to alkylating agents. J Biol Chem 275: 36256-36262, 2000.

51. Strathdee G, MacKean MJ, Illand M and Brown R: A role for methylation of the hMLH1 promoter in loss of hMLH1 expression and drug resistance in ovarian cancer. Oncogene 18: 2335-2341, 1999.

52. Carethers JM, Chauhan DP, Fink D, Nebel S, Bresalier RS, Howell SB and Boland CR: Mismatch repair proficiency and in vitro response to 5-fluorouracil. Gastroenterology 117: 123-131, 1999.

53. Bhattacharjee P, Sanyal T, Bhattacharjee S and Bhattacharjee P: Epigenetic alteration of mismatch repair genes in the population chronically exposed to arsenic in West Bengal, India. Environ Res 163: 289-296, 2018

54. Vivarelli S, Salemi R, Candido S, Falzone L, Santagati M, Stefani S, Torino F, Banna GL, Tonini G and Libra M: Gut Microbiota and Cancer: From Pathogenesis to Therapy. Cancers (Basel) 11: E38, 2019.

55. Banna GL, Torino F, Marletta F, Santagati M, Salemi R, Cannarozzo E, Falzone L, Ferraù F, Libra M. Lactobacillus rhamnosus GG: An Overview to explore the rationale of its use in cancer. Front Pharmacol: doi: 10.3389/fphar.2017.00603.

56. Westwood A, Glover A, Hutchins G, Young C, Brockmoeller S, Robinson R, Worrilow L, Wallace D, Rankeillor K, Adlard J, et al: Additional loss of MSH2 and MSH6 expression in sporadic deficient mismatch repair colorectal cancer due to MLH1 promoter hypermethylation. J Clin Pathol 72: 443-447, 2019.

57. Kang Z, Zhu Y, Zhang QA, Dong L, Xu F, Zhang X and Guan M: Methylation and expression analysis of mismatch repair genes in extramammary Paget's disease. J Eur Acad Dermatol Venereol 33: 874-879, 2019.

58. Mäki-Nevala S, Valo S, Ristimäki A, Sarhadi V, Knuutila S, Nyström M, Renkonen-Sinisalo L, Lepistö A, Mecklin JP and Peltomäki P: DNA methylation changes and somatic mutations as tumorigenic events in Lynch syndrome-associated adenomas retaining mismatch repair protein expression. EBioMedicine 39: 280-291, 2019.

59. Bartel DP: MicroRNAs: Genomics, biogenesis, mechanism, and function. Cell 116: 281-297, 2004.
60. Zimmerman AL and Wu S: MicroRNAs, cancer and cancer stem cells. Cancer Lett 300: 10-19, 2011.

61. Falzone L, Lupo G, La Rosa GRM, Crimi S, Anfuso CD, Salemi R, Rapisarda E, Libra M and Candido S: Identification of novel microRNAs and their diagnostic and prognostic significance in oral cancer. Cancers (Basel) 11: E610, 2019.

62. Hafsi S, Candido S, Maestro R, Falzone L, Soua Z, Bonavida B, Spandidos DA and Libra M: Correlation between the overexpression of Yin Yang 1 and the expression levels of miRNAs in Burkitt's lymphoma: A computational study. Oncol Lett 11: 1021-1025, 2016.

63. Falzone L, Romano GL, Salemi R, Bucolo C, Tomasello B, Lupo G, Anfuso CD, Spandidos DA, Libra M and Candido S: Prognostic significance of deregulated microRNAs in uveal melanomas. Mol Med Rep 19: 2599-2610, 2019.

64. Falzone L, Candido S, Salemi R, Basile MS, Scalisi A, McCubrey JA, Torino F, Signorelli SS, Montella M and Libra M: Computational identification of microRNAs associated to both epithelial to mesenchymal transition and NGAL/MMP-9 pathways in bladder cancer. Oncotarget 7: 72758-72766, 2016.

65. Costa PM and Pedroso de Lima MC: MicroRNAs as molecular targets for cancer therapy: On the modulation of microRNA expression. Pharmaceuticals (Basel) 6: 1195-1220, 2013.

66. McCubrey JA, Fitzgerald TL, Yang LV, Lertpiriyapong K, Steelman LS, Abrams SL, Montalto G, Cervello M, Neri LM, Cocco L, et al: Roles of GSK-3 and microRNAs on epithelial mesenchymal transition and cancer stem cells. Oncotarget 8: 14221-14250, 2017

67. Reinhart BJ, Slack FJ, Basson M, Pasquinelli AE, Bettinger JC, Rougvie AE, Horvitz HR and Ruvkun G: The 21-nucleotide let-7 RNA regulates developmental timing in Caenorhabditis elegans. Nature 403: 901-906, 2000.

68. Cheng AM, Byrom MW, Shelton J and Ford LP: Antisense inhibition of human miRNAs and indications for an involvement of miRNA in cell growth and apoptosis. Nucleic Acids Res 33: 1290-1297, 2005

69. Sasaki CT, Doukas SG and Vageli DP: In vivo short-term topical application of BAY 11-7082 prevents the acidic bile-induced mRNA and miRNA oncogenic phenotypes in exposed murine hypopharyngeal mucosa. Neoplasia 20: 374-386, 2018.

70. Doukas SG, Vageli DP and Sasaki CT: NF-kB inhibition reverses acidic bile-induced miR-21, miR-155, miR-192, miR-34a, miR-375 and miR-451a deregulations in human hypopharyngeal cells. J Cell Mol Med 22: 2922-2934, 2018.

71. Doukas PG, Vageli DP, Doukas SG, Sasaki CT. Temporal characteristics of NF- $\mathrm{kB}$ inhibition in blocking bile-induced oncogenic molecular events in hypopharyngeal cells. Oncotarget: doi: https://doi.org/10.18632/oncotarget.26917.

72. Landau DA and Slack FJ: MicroRNAs in mutagenesis, genomic instability, and DNA repair. Semin Oncol 38: 743-751, 2011.

73. Mao G, Lee S, Ortega J, Gu L and Li GM: Modulation of microRNA processing by mismatch repair protein MutL $\alpha$. Cell Res 22: 973-985, 2012.

74. Valeri N, Gasparini P, Fabbri M, Braconi C, Veronese A, Lovat F, Adair B, Vannini I, Fanini F, Bottoni A, et al: Modulation of mismatch repair and genomic stability by miR- 155 . Proc Natl Acad Sci USA 107: 6982-6987, 2010.

75. Zhong Z, Dong Z, Yang L, Chen X and Gong Z: MicroRNA-31-5p modulates cell cycle by targeting human mutL homolog 1 in human cancer cells. Tumour Biol 34: 1959-1965, 2013.

76. Salemi R, Falzone L, Madonna G, Polesel J, Cinà D, Mallardo D, Ascierto PA, Libra M and Candido S: MMP-9 as a candidate marker of response to BRAF inhibitors in melanoma patients with BRAFV600E mutation detected in circulating-free DNA. Front Pharmacol: Aug 142018 (Epub ahead of print) doi: 10.3389/fphar.2018.00856.

77. Pfeifer GP, Denissenko MF, Olivier M, Tretyakova N, Hecht SS and Hainaut P: Tobacco smoke carcinogens, DNA damage and p53 mutations in smoking-associated cancers. Oncogene 21: 7435-7451, 2002 .

78. Zhong Y, Carmella SG, Upadhyaya P, Hochalter JB, Rauch D, Oliver A, Jensen J, Hatsukami D, Wang J, Zimmerman C, et al: Immediate consequences of cigarette smoking: Rapid formation of polycyclic aromatic hydrocarbon diol epoxides. Chem Res Toxicol 24: 246-252, 2011.

79. Boda D, Docea AO, Calina D, Ilie MA, Caruntu C, Zurac S, Neagu M, Constantin C, Branisteanu DE, Voiculescu V, et al: Human papilloma virus: Apprehending the link with carcinogenesis and unveiling new research avenues (Review). Int J Oncol 52: 637-655, 2018. 
80. Dylawerska A, Barczak W, Wegner A, Golusinski W and Suchorska WM: Association of DNA repair genes polymorphisms and mutations with increased risk of head and neck cancer: A review. Med Oncol 34: 197, 2017

81. Demokan S, Suoglu Y, Demir D, Gozeler M and Dalay N: Microsatellite instability and methylation of the DNA mismatch repair genes in head and neck cancer. Ann Oncol 17: 995-999, 2006.

82. Wang Y, Irish J, MacMillan C, Brown D, Xuan Y, Boyington C, Gullane $\mathrm{P}$ and Kamel-Reid S: High frequency of microsatellite instability in young patients with head-and-neck squamous-cell carcinoma: Lack of involvement of the mismatch repair genes $h M L H 1$ and $h M S H 2$. Int J Cancer 93: 353-360, 2001.

83. Liu K, Huang H, Mukunyadzi P, Suen JY, Hanna E and Fan CY: Promoter hypermethylation: An important epigenetic mechanism for hMLH1 gene inactivation in head and neck squamous cell carcinoma. Otolaryngol Head Neck Surg 126: 548-553, 2002.

84. Murata H, Khattar NH, Kang Y, Gu L and Li GM: Genetic and epigenetic modification of mismatch repair genes $h M S H 2$ and $h M L H 1$ in sporadic breast cancer with microsatellite instability. Oncogene 21: 5696-5703, 2002.

85. Demokan S, Muslumanoglu M, Yazici H, Igci A and Dalay N: Investigation of microsatellite instability in Turkish breast cancer patients. Pathol Oncol Res 8: 138-141, 2002.

86. Ruszkiewicz A, Bennett G, Moore J, Manavis J, Rudzki B, Shen L and Suthers G: Correlation of mismatch repair genes immunohistochemistry and microsatellite instability status in HNPCC-associated tumours. Pathology 34: 541-547, 2002.

87. Shia J, Ellis NA and Klimstra DS: The utility of immunohistochemical detection of DNA mismatch repair gene proteins. Virchows Arch 445: 431-441, 2004

88. Pereira CS, Oliveira MV, Barros LO, Bandeira GA, Santos SH, Basile JR, Guimarães AL and De Paula AM: Low expression of MSH2 DNA repair protein is associated with poor prognosis in head and neck squamous cell carcinoma. J Appl Oral Sci 21: 416-421, 2013.

89. Nogueira GA, Lourenço GJ, Oliveira CB, Marson FA, Lopes-Aguiar L, Costa EF, Lima TR, Liutti VT, Leal F, Santos VC, et al: Association between genetic polymorphisms in DNA mismatch repair-related genes with risk and prognosis of head and neck squamous cell carcinoma. Int J Cancer 137: 810-818, 2015

90. Jha R, Gaur P, Sharma SC and Das SN: Single nucleotide polymorphism in hMLH1 promoter and risk of tobacco-related ora carcinoma in high-risk Asian Indians. Gene 526: 223-227, 2013.

91. Liu K, Huang H, Mukunyadzi P, Suen JY, Hanna E and Fan CY: Promoter hypermethylation: An important epigenetic mechanism for hMLH1 gene inactivation in head and neck squamous cell carcinoma. Otolaryngol Head Neck Surg 126: 548-553, 2002.

92. Liu K, Zuo C, Luo QK, Suen JY, Hanna E and Fan CY: Promoter hypermethylation and inactivation of $h M L H 1$, a DNA mismatch repair gene, in head and neck squamous cell carcinoma. Diagn Mol Pathol 12: 50-56, 2003.

93. Zuo C, Zhang H, Spencer HJ, Vural E, Suen JY, Schichman SA, Smoller BR, Kokoska MS and Fan CY: Increased microsatellite instability and epigenetic inactivation of the $h M L H 1$ gene in head and neck squamous cell carcinoma. Otolaryngol Head Neck Surg 141: 484-490, 2009.

94. Tawfik HM, El-Maqsoud NM, Hak BH and El-Sherbiny YM: Head and neck squamous cell carcinoma: Mismatch repair immunohistochemistry and promoter hypermethylation of hMLH1 gene. Am J Otolaryngol 32: 528-536, 2011.

95. Xinarianos G, Liloglou T, Prime W, Maloney P, Callaghan J, Fielding P, Gosney JR and Field JK: $h M L H 1$ and $h M S H 2$ expression correlates with allelic imbalance on chromosome $3 p$ in non-small cell lung carcinomas. Cancer Res 60: 4216-4221, 2000.

96. Hsu HS, Wen CK, Tang YA, Lin RK, Li WY, Hsu WH and Wang YC: Promoter hypermethylation is the predominant mechanism in $h M L H 1$ and $h M S H 2$ deregulation and is a poor prognostic factor in nonsmoking lung cancer. Clin Cancer Res 11: 5410-5416, 2005.

97. Kanellis G, Chatzistamou I, Koutselini H, Politi E, Gouliamos A, Vlahos L and Koutselinis A: Expression of DNA mismatch repair gene MSH2 in cytological material from lung cancer patients. Diagn Cytopathol 34: 463-466, 2006.

98. Downey CM and Jirik FR: DNA mismatch repair deficiency accelerates lung neoplasm development in K-ras $\left({ }^{\mathrm{LA} 1 /+}\right)$ mice: A brief report. Cancer Med 4: 897-902, 2015.
99. Scartozzi M, Franciosi V, Campanini N, Benedetti G, Barbieri F, Rossi G, Berardi R, Camisa R, Silva RR, Santinelli A, et al: Mismatch repair system (MMR) status correlates with response and survival in non-small cell lung cancer (NSCLC) patients. Lung Cancer 53: 103-109, 2006.

100. Takahashi Y, Kondo K, Hirose T, Nakagawa H, Tsuyuguchi M, Hashimoto M, Sano T, Ochiai A and Monden Y: Microsatellite instability and protein expression of the DNA mismatch repair gene, hMLH1, of lung cancer in chromate-exposed workers. Mol Carcinog 42: 150-158, 2005.

101. Falzone L, Salomone S, Libra M. Evolution of cancer pharmacological treatments at the turn of the third millennium. Front Pharmacol: doi: doi.org/10.3389/fphar.2018.01300.

102. Fink D, Nebel S, Norris PS, Aebi S, Kim HK, Haas M and Howell SB: The effect of different chemotherapeutic agents on the enrichment of DNA mismatch repair-deficient tumour cells. Br J Cancer 77: 703-708, 1998.

103. Vaisman A, Varchenko M, Umar A, Kunkel TA, Risinger JI, Barrett JC, Hamilton TC and Chaney SG: The role of hMLH1, hMSH3, and hMSH6 defects in cisplatin and oxaliplatin resistance: Correlation with replicative bypass of platinum-DNA adducts. Cancer Res 58: 3579-3585, 1998.

104. Hause RJ, Pritchard CC, Shendure J and Salipante SJ: Classification and characterization of microsatellite instability across 18 cancer types. Nat Med 22: 1342-1350, 2016.

105. Microsatellite Instability-Defective DNA Mismatch Repair: ESMO Biomarker Factsheet. [https://oncologypro.esmo.org/ Education-Library/Factsheets-on-Biomarkers/MicrosatelliteInstability-Defective-DNA-Mismatch-Repair\#eztoc1701983_0_0_8/

106. Boyiadzis MM, Kirkwood JM, Marshall JL, Pritchard CC, Azad NS and Gulley JL: Significance and implications of FDA approval of pembrolizumab for biomarker-defined disease. J Immunother Cancer 6: 35, 2018.

107. Chang L, Chang M, Chang HM and Chang F: Microsatellite Instability: A Predictive Biomarker for Cancer Immunotherapy. Appl Immunohistochem Mol Morphol 26: e15-e21, 2018.

108.Zhao P,Li L, Jiang X and Li Q: Mismatch repair deficiency/microsatellite instability-high as a predictor for anti-PD-1/PD-L1 immunotherapy efficacy. J Hematol Oncol 12: 54, 2019.

109. Garon EB, Rizvi NA, Hui R, Leighl N, Balmanoukian AS Eder JP, Patnaik A, Aggarwal C, Gubens M, Horn L, et al; KEYNOTE-001 Investigators: Pembrolizumab for the treatment of non-small-cell lung cancer. N Engl J Med 372: 2018-2028, 2015.

110. Reck M, Rodríguez-Abreu D, Robinson AG, Hui R, Csőszi T, Fülöp A, Gottfried M, Peled N, Tafreshi A, Cuffe S, et al, KEYNOTE-024 Investigators: Pembrolizumab versus Chemotherapy for PD-L1-Positive Non-Small-Cell Lung Cancer. N Engl J Med 375: 1823-1833, 2016.

111. Pylkkänen L, Karjalainen A, Anttila S, Vainio $\mathrm{H}$ and Husgafvel-Pursiainen K: No evidence of microsatellite instability but frequent loss of heterozygosity in primary resected lung cancer. Environ Mol Mutagen 30: 217-223, 1997.

112. Merlo A, Mabry M, Gabrielson E, Vollmer R, Baylin SB and Sidransky D: Frequent microsatellite instability in primary small cell lung cancer. Cancer Res 54: 2098-2101, 1994.

113. Mao L, Lee DJ, Tockman MS, Erozan YS, Askin F and Sidransky D: Microsatellite alterations as clonal markers for the detection of human cancer. Proc Natl Acad Sci USA 91: 9871-9875, 1994.

114. Chen XQ, Stroun M, Magnenat JL, Nicod LP, Kurt AM, Lyautey J, Lederrey C and Anker P: Microsatellite alterations in plasma DNA of small cell lung cancer patients. Nat Med 2: 1033-1035, 1996.

115. Hansen LT, Thykjaer T, Ørntoft TF, Rasmussen LJ, Keller P Spang-Thomsen M, Edmonston TB, Schmutte C, Fishel R and Petersen LN: The role of mismatch repair in small-cell lung cancer cells. Eur J Cancer 39: 1456-1467, 2003.

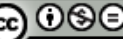

This work is licensed under a Creative Commons Attribution-NonCommercial-NoDerivatives 4.0 International (CC BY-NC-ND 4.0) License. 